Article

\title{
Christian Ethical Analysis of the L.A. Riots in 1992: The Media and Institutional Racism
}

\author{
Yong Sup Song \\ Department of Theology, Youngnam Theological University and Seminary, Gyeongsan 38451, Korea; \\ ysbius@gmail.com
}

Received: 16 May 2020; Accepted: 8 July 2020; Published: 9 July 2020

\begin{abstract}
This essay utilizes Reinhold Niebuhr's theology of the universality of sin to analyze institutional racism, using the 1992 Los Angeles riots as a case study. Contrary to the conventional interpretation of the riots as a conflict between African Americans and Korean Americans, the pervasive institutional racism of the mainstream media of that era spread the riots into multiracial conflicts, which explains Niebuhr's thinking regarding the universality of sin. Furthermore, the sensationalism of the media that fueled the massive violence deprived African Americans of the moral dynamic for social transformation and victimized Korean Americans as scapegoats. As a result, the institutional processes promoted the status quo that benefited the white privileged class at the expense of the racial minorities. Implications found in this essay may be applicable to current issues, such as anti-Asian racism that has surfaced during the COVID-19 pandemic in the United States.
\end{abstract}

Keywords: the L.A. riots; racism; sin; the media; Reinhold Niebuhr

\section{Introduction}

When racial tensions surface in a community, violent behavior sometimes erupts, which can result in long-term, socio-political, spiritual, and communal turmoil. Regretfully, the responses of social institutions to such crises are often discriminatory and racially driven. During the last thirty years, the racism that resulted in the Los Angeles riots of 1992 has been neglected in the field of Christian social ethics, with minimal scholarly research, investigation, or publications related to the event.

This study applies the Christian ethical thought of Reinhold Niebuhr to the analysis of institutional racism and exposes such racism as the fundamental factor in the furious violence directed toward Korean Americans during the 1992 L.A. riots. The uniqueness of this essay is in the application of Niebuhr's thought of the sin of pride to a historical event that has not been sufficiently discussed among American Christian ethicists despite its disastrous results. In particular, this study focuses on investigating how Korean merchants were victimized by the institutional racism generated by the sensationalism of the mainstream mass media of the era, and how Niebuhr's thought regarding the universality of sin can be critically applied to such racism. While the works of scholars such as Mary Douglas and Noam Chomsky have contributed to this essay, Niebuhr's contribution to thinking about institutional racism mainly helps to ascertain both how the sin of pride is manifested in racial groups by prejudice and violence, and how racism is represented in the institutional processes and failures of the mass media of the era.

Niebuhr regarded all human beings as sinners before God due to the sin of pride and the desire to become God-like. Such human sin is pervasive in social structures as systems of power that are organized and rationalized by people with moral and spiritual pride. The critical utilization of Niebuhr's universality of sin reveals institutional racism whose consequences were extreme as the media engaged with unbridled authority. This phenomenon is clearly visible in the mainstream media's selective and sensational coverage of the L.A riots as biracial conflicts. The result of this 
erroneous emphasis was the attribution of the cause of the conflicts to racism within racial minorities and the erasure from the public memory of the catalytic role of the political agents that represented the structural racism that was not as readily evident to the public.

Throughout this essay, an in-depth analysis of the L.A. riots unveils a tragic but pertinent example of the prevalence of the corruption of public opinion caused by the sin of pride. The application of Niebuhr's theology debunks the self-deception and self-justification of those who benefited from the effects of that racism. Although human sinfulness is pervasive in all human interactions, as noted in Niebuhr's thought of the universality of sin, critical ethical theories can help to identify how deeply sinfulness is manifested and rooted, explicitly and implicitly, in the functions and processes of racialized institutions.

\section{Brief History of the 1992 L.A. Riots}

The violence in the L.A. riots began on 3 March 1991 with the merciless beating of an African-American male, Rodney King, by four white police officers, an event that was captured on video and shown on national television news networks. With multiple criminal charges, the popular consensus was that these officers would be found guilty in a court of law. On the contrary, their acquittal was announced on 29 April 1992, which "undermined and discredited faith in the legal system" for many people (Abu-Lughod 2007). As a result, many protesters gathered in South Central L.A. on that day were outraged at the news. The initial demonstrations were not only protests against the unfair verdicts of the trial, but also represented an outcry for justice for African Americans, who had suffered a long history of unjust socio-economic institutional racism in U.S. society. However, the scattered protests soon escalated into massive violence, fueled by inappropriate institutional responses and resulting in thousands of arrests and injuries, including fifty-one fatalities in six days, together with approximately $\$ 1$ billion in property damages (Bergesen and Herman 1998).

From the beginning of the violence, however, the police force was found to be ill-prepared for such violence and responded inappropriately to what was labeled as a riot (Abu-Lughod 2007). During the first twenty-four hours after the outbreak of the riot, South Central L.A. incurred severe damage. During the following days, "conditions in South Central rapidly worsened" and "looting and arson intensified," even though a state of emergency was declared and a curfew was imposed (Abu-Lughod 2007). "No police [were] present" until Thursday afternoon, April 30, when, finally, "the first National Guard troop was deployed," and they started to gain control over the area (Abu-Lughod 2007). On May 1, President George H. W. Bush federalized the National Guard. During the following days, National Guard troops were deployed to control the city, and the riot was considered officially over on May 2.

The sensational reporting of the L.A. riots by the TV broadcasting and newspapers, such as ABC, CNN, and the Los Angeles Times, functioned to discriminate against specific racial minorities. The media's inappropriate responses not only exacerbated violence through unintentional processes of filtering, but also sometimes constructed racial identities through the manipulative portrayals of the L.A. riots. That is, the mainstream mass media framed the riots mainly as a biracial conflict between Korean Americans and African Americans, ignoring the multiracial nature of the conflict. Such institutional racism reinforced the marginalization of Korean Americans and African Americans in the area in addition to ultimately causing extensive property damage and personal injury.

\section{The Analysis of the 1992 L.A. Riots: The Media and Institutional Racism}

While Niebuhr did not explicitly analyze the power of the mass media, scholars such as Mary Douglas and Noam Chomsky provide valuable complementary material that enriches Niebuhr's work on the sin of pride so that it is valuable for engaging in analysis of the institutional racism of the mass media. In her book How Institutions Think (1986), Mary Douglas explains how institutions are established, function, and are sustained in relation to their members. Her explanation is that individuals build an institution for their benefit, and give it authority through voluntary consent. In turn, 
the institution provides members with "a set of analogies with which to explore the world and with which to justify the naturalness and reasonableness of the instituted rules, and it can keep its identifiable continuing form" (Douglas 1986). Then, with given authority bolstered by the analogy of naturalness and reasonableness, the institution starts to control the cognitive system of its members, compelling it both to remember and to forget things according to its compatible rules, images, and world-views. According to Douglas, "Institutions create shadowed places in which nothing can be seen and no questions asked. They make other areas show examples of discrimination in detail, which are closely scrutinized and ordered. History emerges in unintended shape as a result of practices directed to immediate, practical ends" (Douglas 1986). Institutions construct and revise the past events according to their practical needs and ends of the present, although they would appear as if unintended.

Douglas' ideas help us to analyze how the mass media is legitimized by society's consent and, thereafter, how it affects the public memory for its specific ends as a social institution. In particular, the media, as one of the most important institutions of a democratic nation, functions to construct and erase collective memory (Edy 1999). The media influences the public to either remember or forget the past, depending on the needs of the institution, through official procedures of selecting and regulating the stories and images.

In the case of the L.A. riots, Korean Americans and African Americans were victimized by stereotyping embedded in broadcasting and news articles through the media's sensationalism. In such coverage of the massive violence, the media excluded and silenced the voices of Korean Americans. Before the outbreak of the L.A. riots, the mainstream media chose not to publicize the stories of the suffering in the Korean American community, and thus excluded them from the public memory. Angela Oh remarks that "Mainstream media does not pick up the stories we hear in the Korean-language press and media every day-about another gunshot incident, another assault" (Oh 1994). Nancy Abelmann also states: "With a few exceptions ... Korean Americans were virtually shut out of the mainstream media in the United Sates. They were widely discussed but largely silent" (Abelmann and Lie 1995). Such selective responses of the mainstream mass media also resulted in the manipulation of Korean American merchants as scapegoats of these racial conflicts.

Stories and articles by the media may affect the way people see themselves and others, as well as the relevance of the past to the present (Edy 1999). The authority of the media in its reporting partly came from the "claim that they are factual accounts of what 'really' happened" and that the news images and stories have "more powerful emotional connections on the part of the audience" through the media's authority (Edy 1999). However, media reports of crime often promote incorrect interpretations and judgments to the viewers. The crime images of the news are often "racialized" and contribute to the maintenance of the racial prejudice against minority groups (Dowler 2004). With the authority that it was given, the media in the L.A. riots constructed and maintained negative identities of racial minorities, which reinforced white racism (Palumbo-Liu 1994). In the process of reporting, the media hid or erased present and past events according to their own assumptions and motivations. For example, many African Americans were there on the street helping victims of the riots, but they were not reported in the broadcasting. The media rediscovered the past events, emphasizing racial conflicts between minorities, and revised them into new meaningful events for the present. Consequently, socially constructed narratives were planted in the public memory through their institutional processes. As a result, the racial conflicts and the stories of suffering of the Korean American community, which had long been neglected, were suddenly chosen and promoted into news bytes to increase advertising and the sale of newspapers.

In Manufacturing Consent, written with Edward Herman, Noam Chomsky argues that the mass media functions as "systemic propaganda" for specific interests that serve the dominant group and the status quo, rather than as the deliverer of free opinions for the common good of the public (Herman and Chomsky 2002). The media intentionally propagandizes the specific interests of power groups, especially those who "control and finance" them through the process of "filtering" (Herman and Chomsky 2002). Filtering refers to the way the media selectively reports issues in order to maximize revenue. Chomsky 
argues that the process of such propaganda "is normally not accomplished by crude intervention, but by the selection of right-thinking personnel and by the editor's and working journalists' internalization of priorities and definitions of news-worthiness that conform to the institution's policy" (Herman and Chomsky 2002). That is, the mass media is capable of filtering and manufacturing the news and opinions to be used by the powerful for their own messages to be delivered to the public (Herman and Chomsky 2002). The process of propagandizing their dominant ideology is so discreet that "media news people, frequently operating with complete integrity and goodwill, are able to convince themselves that they choose and interpret the news 'objectively' and on the basis of professional news values" (Herman and Chomsky 2002). Chomsky's theory highlights that the mass media affects the cognitive systems as well as the behaviors of its members once it is established as an institution. People react to the reports of the mainstream mass media and internalize the ideas, norms, and values presented by the institution because no one can directly observe all the events around the world (Johansen 1996). The propaganda theory suggests that the white-owned mainstream mass media coverage of the L.A. riots was also a filtered product to serve white domination, even though the reporters did not recognize their bias.

The media affects our "attitude, values, and behaviors" because of its pervasiveness in society (Pieraccini 1997). The media produces stories and images with exclusive authority granted by the consent of the audiences, which affect the public memory. When providing the audiences with racially biased messages and images, the media controls the public memory by stereotyping against racial minorities to benefit the privileged white to support the status quo at the expense of other racial groups. For example, KABC repeatedly broadcasted the edited footage of Soon Ja Du's shooting of a black girl on 16 March 1991, emphasizing her ethnic identity during the 1992 riots, which stereotyped Korean merchants as if they were the cause of the biracial conflicts.

During the L.A. riots, the mainstream media played a significant role by making "the whole world witnesses to history... At one point, there were 14 or more helicopters from various media organizations... informing the public" (Webster 1994). Hovering over the districts in their helicopters, the media looked over the shocking events of violence, looting, and arson, witnessing and broadcasting the sins of the mob, as if they were the gods of omniscience and omnipresence. In the sky above the riot locations, the media cameras in the helicopters consistently zoomed in and out on the scenes of violence. Throughout such violence, the media was presented as the towering center of information on which the entire world relied. The media repeatedly broadcasted sensational footage of the riots into the homes of Americans and the rest of the world, generating images that nurtured stereotypes and erroneous notions of minorities' behavior.

In the case of the L.A. riots, the broadcasting of the mainstream mass media inflamed the conflict situations by allowing some of the minority communities to join in the looting and arson of unattended businesses. Berry et al. pointed out, "Local media newscasts provided looters with ready-made road maps to neighborhoods where looting was underway or where the police cover was thin or nonexistent" (Berry et al. 1999). The following example is the transcript of a segment of live news coverage by ABC during the early stages of the L.A. riots that provides information on the looting and the lack of proper response by the police at the site.

[Reporter] The people are back inside. They have started looting again. The police officers at this point are protecting the firefighters who are working on this fire here, the Newberry store on Western at 18. And so, what you have there, people have gone back inside the store. They feel that they can do this now with impunity. There's a lady coming out right now out of the main entrance. Look at her, her arms are full of material there. Full of stuff. People going in. The police see it. They know what's going on. But at this point, apparently, they feel that they can do nothing about it. So, there you see people. It looks, it looks, it looks almost as they go their shopping, in a sense. you know?... It just looks like, kind of like, people are in their shopping... (ABC7 2020) 
On the live broadcast, the reporter describes the crime scene at a shopping mall with detailed information on the location, the police response, and the looters. The looting is portrayed as if they were shopping. It is described that people can take anything at will, even when the police are present there. Since the live broadcast of the scene gives an accurate address of the looting, people who watch the live coverage at home think that they may go there and enjoy free shopping, too.

In addition to the broadcasting, Hermant Shah and Michael Thornton argue that the newspapers also emphasized the L.A. riot as the result of "conflict mainly between Blacks and Korean Americans" by eliminating the involvement of Latinos in the riots (Shah and Thornton 2004). In fact, more than half of those arrested were Hispanic (Morrison and Lowry 1994). Furthermore, according to Lou Cannon, television coverage created "a demonic view of African Americans. All the assailants and none of the victims in Florence and Normandie were blacks," while "the heroic actions of blacks who stood up to the mob and rescued whites, Latinos, and Asians from death" were hardly known to the public (Cannon 1997).

By providing such filtered information, the mainstream mass media constructed, redefined, and erased the scenes of violence and race depending on their various racial assumptions. The initial news narratives about the violence mostly "avoided criticizing the rioters and their actions," sympathetically focusing on "the motivations of the rioters," were open to "the possibility of understanding," and condemned the jurors of the Simi Valley Court and the police by contrasting the LAPD's aggressiveness in the beating of Rodney King with their passiveness in handling the 1992 riots (Jacobs 2000). After the construction of racial images of African Americans and Korean American merchants, however, the mainstream media started to propagandize its own biased knowledge to criticize both of the groups.

Chomsky's analysis of the media and "media news people" resonates with Niebuhr's claim of the qualitative difference in individuals situated in private and group realms. When individuals were in group relations, such as the reporters and the journalists of the media as institutions, they manipulated African Americans and Korean Americans by producing biased messages even though they might have had goodwill as well-intentioned individuals.

Moreover, Niebuhr's thinking on the sin of pride explains why the media is tempted to serve the interests of powerful groups, as it was exercising an unprecedented authority to influence the public memory. Niebuhr claimed that, in the case of conflicts between groups of unequal privilege, the privileged justify their racial assumptions by stereotyping the racial minorities in a negative manner, especially for their own economic interests (Niebuhr 1957a).

In particular, Niebuhr understands the sin of pride as the basic evil embedded in human nature that leads to racism. The sin of pride, Niebuhr argues, lies in the ignorance and pretension of humans when we come to believe, out of anxiety, that we can transcend our own finitude and become like God (Niebuhr 1996). Niebuhr believed that the manifestation of the sin of the pride, such as in pretense and egoism, was more magnified in group pride than in that of individuals (Niebuhr 1996). Group pride is easily exhibited in racial pride. With the sin of pride, the majority group with power asserts self-mastery and seeks security at the expense of others.

Niebuhr argues that sin is universal (Niebuhr 1996), which is like a double-edged sword. The concept of the universality of sin should be applied to the analysis of institutional racism critically because it often leads to the promotion of "morally equating oppressor and oppressed precisely by encouraging acontextual, universalizing definitions of $\sin ^{\prime \prime}$ (West 2006). Furthermore, Niebuhr was criticized for his lack of acknowledgment of the discrimination that African Americans had suffered for decades. According to James Cone, during the civil rights movement of the 1960s, he was a "powerful theological voice," but "never risking his life in the fight for justice" (Cone 2011). However, Niebuhr's view of racism as a universal problem may be an effective source with which to confront the distortion of institutional racism so as to assign a sense of accountability to all parties, including hidden ones, such as the mass media in the L.A. riots. 
Racism, as a sin of pride, may be seriously worsened in group pride because the capacities for self-transcendence in collective life are considerably limited, while individual responsibilities may be maintained in personal relations. Furthermore, it is pervasive not only among the oppressors, but also among the oppressed. Racism as sin permeates all individuals and all socio-economic groups, with victims sometimes becoming perpetrators. This propensity was manipulatively emphasized with conventional reports by the mass media during the L.A. riots. African Americans and Korean Americans, who had experienced personal and structural racism, were sometimes portrayed as the oppressors, which was exemplified in the media reports of Soon Ja Du and the looters.

Studies on framing may help to grasp the institutional racism by the mass media in the rapid deterioration of the L.A. riots. According to Gamson and Modigliani, "A frame is a central organizing idea or story line that provides meaning to an unfolding strip of events, weaving a connection among them" (Gamson and Modigliani 1987). Based on their ideas, Gross and D'Ambrosio argued, "Framing effects suggest that emotions can be manipulated by providing people with different types of information, or by highlighting some aspects of an issue at the expense of others" (Gross and D'Ambrosio 2004). They further claimed that frame effects on emotional content "may subsequently affect opinion or behavior" (Gross and D'Ambrosio 2004).

The mainstream mass media framed the riots as biracial conflicts by highlighting the racism present between minority groups. In the frame of biracial conflicts, the riots were presented as a case in which the African American rioters exercised their power to pursue their own interests at the expense of the Korean Americans with their own motivations. Such binary claims seem to have been the basis for the distorted portrayals that most people received from the frame by the mainstream mass media during the event.

The framing of the L.A. riots as biracial conflicts, however, is invalid, and so must be broken down because certain sinful traits were, in fact, prevalent among all racial groups involved in these riots. Both African Americans and Korean Americans had been prejudiced against one another before the outbreak of the L.A. riots. In addition, the interaction of African Americans and Korean Americans had been influenced by misunderstandings of each other's culture. Even before coming to the United States, Koreans had developed prejudices against African Americans, referring to them as "criminals, welfare recipients, alcoholics, drug addicts...," as they were often portrayed in many American movies and television shows in South Korea (Chang 1999). Meanwhile, some African Americans are prejudiced against Koreans through the internalization of Asian stereotypes, which view Korean merchants as greedy and rude aliens who unfairly compete with African American businessmen (Cho 1993).

In the L.A. riots, large numbers of Hispanics were also engaged in the looting. Furthermore, whites were directly and indirectly involved in the riots. The whites were often invisible in the reports of the scenes of riots, which eliminated an inquiry "into the structure of an economic system that historically has pitted Asians against blacks and Latinos ...." (Palumbo-Liu 1994). However, Pyong Gap Min points out, “Many Korean Americans, including Korean American scholars, have claimed that during the Los Angeles riots, Korean merchants were used by White people to shield themselves from African Americans' hostility" (Min 1996). Some scholars also argue that "the situation required a 'scapegoat' to bear the rage and complaints of blacks about racial injustice and economic inequality" (Lee 1999).

Therefore, it is problematic that the conventional representations by the mass media of the L.A. riots as biracial conflicts made racism among minorities visible. The media functioned to indict the racial minorities by perpetuating vivid images of violence and by emphasizing the racism within the racial minorities. As a result, the white racism in social structures was overlooked and made invisible in the frame of the biracial conflicts.

With the complexity of racial relations, Niebuhr's thought of the universality of sin should not be used to exclusively blame the racial minorities for the massive riots. Although the racism between minority groups was a clear contributing factor, institutional racism remains to be properly investigated. Conversely, Niebuhr's universality of sin should be critically applied in such a way as to expose the 
complacency of the white majority in the case of the L.A. riots. Niebuhr's claims may also be vital for analyzing the self-deception and self-justification of white privilege. Theologian Langdon Gilkey explains that the purpose of Niebuhr's argument on the universality of sin was mainly "to pierce this false veil and see the pride, self-concern, and cruelty of the 'moral' upper class"' (Gilkey 2001).

Niebuhr believed that the theological understanding of the universality of human sinfulness "actually supports rather than contradicts the prophetic strictures" against the socially, economically, and morally privileged (Niebuhr 1996). Niebuhr's idea regarding the universality of sin reveals the institutional racism of the mass media that played a specific role in fueling the violence of the riots, which helped the privileged whites to indirectly benefit from the sustained social systems. If Niebuhr's claims could be employed to "pierce the false veil" of white racism hidden in the inappropriate responses of the mass media, the self-deception of the privileged whites who benefited from the riots at the expense of racial minorities would be clearly exposed.

In Niebuhr's view, it is a form of the sin of pride that blinds the mass media with self-deception and causes it to conceive itself as just and unbiased. Exercising their institutional power to influence the public perception with their own assumptions and norms reduced the multiracial nature of the conflicts into a biracial event between African Americans and Korean Americans. The issues of the structural injustice against minorities and the involvement of other ethnic/racial groups, such as Hispanics and whites, were largely put into "the shadowed places," while racism between two minorities was highlighted and depicted in detail in the manipulative framework of biracial conflicts (Kim 1999).

The violence in the L.A. riots has often been used to blame both Korean Americans and African Americans as the agents of violence, which is, in fact, an example of the double victimization of minorities. The sensational coverage of the mass media was not value-neutral, rather but biased reports that helped the promotion of the status quo and perpetuation of structural racism. Thus, Niebuhr's critique of the sin of pride exposes the institutional racism of the mass media that served the white privileged class through self-deceiving institutional processes. The mainstream mass media defined the victims of the L.A. riots with unidirectional power by selectively reporting the violent situations that controlled the public memory of U.S. society.

Furthermore, as Cornel West insists, the very fact that the 1992 L.A. riots are almost forgotten by the mainstream media and are so gone from the public memory represents how much the events have been racialized (West 1993). Douglas' argument reinforces West's claims: "Public memory is the storage system for the social order .... Some patterns of public events get stored there, others get rejected" (Douglas 1986). In other words, the L.A. riots in 1992, once constructed as biracial conflicts, were rejected from being stored in the public memory through the mass media's filtering for its own interests (Kurtz 1993). After the L.A. riots in 1992, when the mass media of that era did not need to probe the fundamental causes of the riots any longer, the institution obscured the narratives of minorities and covered them up as "the shadowed places," which promoted the status quo. Therefore, the suffering of Korean Americans and African Americans was erased from the public memory through the institutional process, which may be criticized as a form of the sin of pride on the part of the mass media according to Niebuhr's understanding of pride and universal sin.

Niebuhr's theology of the sin of pride, along with the views of Douglas and Chomsky, provides an ethical basis for the critical analysis of the institutional racism of the mainstream mass media. That racism was reflected in the institutional function of the mainstream mass media, shaping and erasing the public memory for their own interests, or, more specifically, for the interests of the white privileged class - who owned and funded the media - at the expense of the racial minorities.

Niebuhr's universality of sin claimed that human sinfulness permeated into institutions such as the mass media through the process and the representatives of the institutions that worked inappropriately on behalf of their own interests. Niebuhr's arguments regarding the universality of sin enlighten us to the fact that the social institutions were inclined to work for some of the specific interest groups in their authorized processes. Thus, they were required to be guided and checked consistently, reflecting the principles of justice. 
Niebuhr's theology of the universality of the sin of pride helps to understand that the L.A. riots were fundamentally fueled by institutional racism of the mass media against Korean American and African American communities under unjust social structures, rather than by existing racism within the minorities. Selective and discriminatory responses of the media repeatedly victimized the African and Korean American communities. Many African Americans were led to violence, such as looting, vandalism, and arson in the riots, by the sensational broadcasting of the mass media. Korean American merchants were targeted for violence and were identified as both the oppressed and the oppressor in their relationship with the African American community. The African American community was deprived of the dynamics and moral basis for justice to fight the racism embedded in the social structures of U.S. society as a result of the institutional racism within numerous institutions. In the frame of biracial conflicts, the racial conflicts and violence between African Americans and Korean Americans were highlighted, while those involving Hispanics were often minimized or removed from the scenes of broadcasts. The victimization of Korean American and African American communities by the mainstream media functioned to strengthen the status quo in U.S. society. In this sense, actors involved in the L.A. riots in 1992 were not simply African Americans and/or Korean merchants, or Hispanics. Actors that facilitated the L.A. riots should have also included the mainstream mass media, as well as the privileged whites with power, who stayed behind the scenes, but were able to preserve their own interests.

The institutional racism within the framework of biracial conflicts, the structural cause of the L.A. riots, became blurred amidst one of the largest civil uprisings in U.S. history. The L.A. riots did not bring about significant social change, nor was there structural reform against racism in U.S. society. This historic event was subsequently erased from the public memory by the selective processes and functions of the mass media.

\section{Public Memory of the 1992 L.A. Riots after Twenty Years}

It is important to compare two news articles of the Los Angeles Times and of the Korea Times that contain the findings of two contrasting polls on race relations in the L.A. areas in April 2012. They appeared in the two newspapers to commemorate the L.A. riots of twenty years before. The language barrier in the poll of the Los Angeles Times was not an issue because the survey was conducted in English, Spanish, and Korean for the target ethnic groups, and the results were similar among different racial and ethnic respondents. The Los Angeles Times article made the following statement on the survey, which was conducted by the Center for the Study of Los Angeles at Loyola Marymount University (LMU).

Most ... say L.A. is unlikely to see riots in the coming years like those that swept the city after the 1992 acquittals of four Los Angeles police officers ... . On race relations, Los Angeles residents were strongly positive, with nearly seven in ten respondents saying the city's racial and ethnic groups were getting along well ... The survey, conducted every five years since the riots, found the large majorities of the four major racial and ethnic groups-Latinos, African Americans, Asian Americans, and whites—said all communities are getting along 'very well' or 'somewhat well'. (Trounson and Rubin 2012)

On the other hand, the Korea Times, published in Korean for Korean-speaking communities in the U.S. society, polled four hundred Korean American residents of Los Angeles, including the people who had experienced the L.A. riots. The poll findings suggest the following.

With Los Angeles' Korean American respondents, nearly seven in ten respondents said, 'It is likely that the riots could occur again due to racial conflicts, at least with some probability.' ... Regarding the relationship between African Americans and Korean Americans, 46.4 percent responded that it still needs improvement, while 34.7 percent answered that risks still exist ... . In particular, the survey found that among the respondents, the generations who 
had lived in the U.S. before the 1992 riots and experienced the riots directly and indirectly felt to a higher degree that they needed to improve the relationships among Korean Americans, African Americans, and Hispanic Americans [translation is mine]. (Kim 2012)

The two polls, conducted on similar topics around the same time, revealed a differing degrees of opinions, and the Los Angeles Times and the Korea Times reported these opposite results to their target readers. Regarding these contradictory survey results in the two newspaper articles, it is supposed that their readers are different from each other. The main readers of the Los Angeles Times are English-speaking residents, while those of the Korea Times are a Korean-speaking minority. In addition, it can be inferred that the survey reported by the Los Angeles Times was more scientifically conducted than that of the Korea Times, which is not as clear with how its survey was conducted. Nevertheless, it is interesting to note that the responses of hundreds of Korean Americans who answered the questions of the Los Angeles Times in the Korean language were significantly different from those of the Korea Times survey.

However, rather than the methodologies or results of the surveys, what we should note is that the reports of the surveys were selected and constructed according to the practical ends of each media institution. In other words, while the survey results reflect the popular opinions, they should be consistent with the practical needs and assumptions of the newspapers. As Douglas points out, "A new discovery has to be compatible with political and philosophical assumptions if it is to get off the ground in the first place ... memory is socially structured" (Douglas 1986). Douglas instructs us that the media's construction of past events appears in an unintended form through the practices toward practical ends, and that some events are obscured and deleted, while others are highlighted and remembered according to the present needs and assumptions of the media. The media, as an institution, selects and interprets meaning, so that it makes a specific event more important than other events and ideas. By selecting specific events and meaning-making processes out of its own needs, the mass media pursues its own interests through its established processes.

While TV news coverage constructs the public memory with instant audio-visual images in a limited time, providing a sense of realism, newspaper articles formulate it with refined and detailed texts that are more reliable to readers. However, their realism and reliability are, in fact, selective, biased, and not value-neutral in the delivery of information regarding the events. The case of these two contradictory survey results is no different. The Los Angeles Times, as part of the mainstream mass media, may have hoped to convey a message of "forget the past; race is not a problem" to its majority of English-speaking readers of multicultural communities in the L.A. area, while the Korea Times may have attempted to deliver that of "never forget the past; race is still a problem" to its Korean-speaking readers in Los Angeles. Perhaps the readers of the Los Angeles Times do not want to remember the shameful memories of the violent riots in 1992, or they may have already forgotten the history of racism that is pervasive among all racial and ethnic groups, while the Korean-speaking readers of the Korea Times would want to keep remembering it as a means of avoiding being victimized by the violence of other racial and ethnic groups. Korean Americans of the poll from the Korea Times seem to believe, at least, that if the Korean American community, as well as other racial and ethnic communities, forgets the unfortunate event and its lessons, it runs the risk of being repeated again. Thus, they required the improvement of racial relationships between Korean and African Americans, as well as between Korean and Latino Americans, to prevent the recurrence of the riots (Kim 2012).

Five years later, in 2017, the Los Angeles Times reported new survey results, "For the first time since the riots, there is an uptick in the number of Angelenos who fear that another civil disturbance is likely ... Nearly 6 out of 10 Angelenos think another riot is likely in the next five years" (Kim and Etehad 2017). The Los Angeles Times cited the police shooting in Ferguson, the tone of the 2016 presidential election, and suffering from economic disparities as some factors for the opinion change (Kim and Etehad 2017). As the political and economic landscape of U.S. society shifted, in 2017, the Los Angeles Times reported the majority opinion, which expected riots to happen again, in detail. 
However, the main problem of the Los Angeles Times was that no Korean American voices were heard in the articles. In fact, Korean Americans were among the greatest victims of the 1992 L.A. riots. Although seventy percent of the respondents were already concerned that the riots were likely to occur again in the Korea Times in 2012, the voices of the Korean American community in the L.A. areas continued to be erased or silenced in the mainstream media.

In the 2012 report of the Los Angeles Times, the opinions of Korean Americans, the voices of the greatest victims, were obscured, as they were buried in the category of Asian Americans in a quarter of the survey subjects. Furthermore, in the 2017 report, one of two journalists was a Korean (or, Korean American) born in Seoul and educated in the U.S. Ironically, even though there seemed to be no language or cultural barriers between the journalist and potential Korean American interviewees, no Korean American was ever interviewed or quoted, while there were nine interviewees of other races and ethnicities with direct quotes in the article. The voices of Korean Americans were not quoted because they were not compatible with the assumptions of the Los Angeles Times that economic suffering of blacks and Latinos may be a cause of new riots. For example, the Los Angeles Times reported that the poll found economic disparities in the racial groups of the poll. Pessimism was more evident in unemployed or part-time workers as well as in "black and Latino residents, compared with whites and Asians" (Kim and Etehad 2017). It may be inferred that the Los Angeles Times did not listen to the voices of Korean (Asian) Americans because it is assumed that Korean Americans, categorized with whites, do not belong to the category of victims of economic inequality, unlike African American and Latino residents.

However, one of the most important lessons of the 1992 riots, apart from the economic problems of racial minorities as a cause of riots, was that Korean Americans were violently sacrificed as a scapegoat for the status quo by means of institutional processes of the media. If it allows this shameful lesson of history to be forgotten, a majority of U.S. society may conveniently turn Korean Americans into victims of violence through institutional racism once again as racial tensions arise between elite whites who enjoy the greatest benefits of economic disparities and racial minorities who are suffering the most. Therefore, the Los Angeles Times, as part of the mainstream media that ignored and erased the voices of Korean Americans in the articles on the 20th and the 25th anniversaries of the L.A. riots, has continuously engaged in actions illustrating institutional racism, as it did 20 and 25 years before. Remembering and forgetting in public memory through the media, as in the case of the 1992 riots and thereafter, remind us how difficult it is to eliminate racism in institutions as well as individuals, as Niebuhr said.

\section{Conclusions}

Through a Christian ethical analysis of the L.A. riots, this essay offers a contemporary interpretation of the sin of pride in the formal processes of the mass media, and reveals the grave effect that institutional racism as a sin of pride has had on the lives of racial minorities. In particular, the media's cognitive controls on the public memory are critically analyzed. Niebuhr's claims of the universality of sin help us to scrutinize the fundamental nature of human sinfulness of all the involved racial groups and, especially, the institutional racism that has been involved in the institutional processes of the mass media. Thus, Niebuhr's thought about sin requires the vigorous pursuit of justice to resist the institutional racism and of the creation of a system of checks and balances against the potential manipulation of the institutional authorities by the privileged for their own sake. The pervasiveness and persistence of racism as the sin of pride in social relations require continued criticism from the perspectives of racial minorities, who have been victimized and silenced by the media, as a means of checks and balances.

At the same time, however, Niebuhr advised us that racism as the sin of pride would never be fully overcome because members of racial groups, whose interactions would be amplified in collective lives, could not be completely exempted from the sin of pride in the institutional processes (Niebuhr 1957b). Perhaps, once we confront the sin of racism within us and vigorously resist against institutional racism, 
this would increase the possibility of justice among racial groups and the institutions, as we have learned from Niebuhr.

This paper serves as the groundwork for further studies on the theological analysis of group behaviors and the interpretation of the functions of social institutions. Not only the overt group conflicts, but also the covert functions of social institutions may be critically analyzed to reveal the specific group interests that work behind their formal processes and procedures. Such functions reflect that the sin of pride is a fundamental basis of institutional racism, as it penalizes and disadvantages racial minorities.

For example, this study may be applied to the analysis of racism and hate assaults on Asian Americans during the COVID-19 situation, which have been incited by rhetoric in the media as well as in politics. In particular, hate speech made by Trump at his campaign rallies has included rhetoric such as "invasion" and "killer" to refer to immigrants more than 500 times (Fritze 2019). He even made a joke in a Florida rally when audience participants shouted "Shoot them," referring to immigrants (Rieger 2019). White supremacist language seems to be normalized under the Trump administration. As racism and anti-immigrant hostility have increased, Asians have become targets of derogation in the mass media and politicians' statements since the outbreak of COVID-19 (HumanRightsWatch 2020). Politicians' rhetoric of calling COVID-19 the "Wuhan virus" or "Chinese virus," which was repeated in the media, fueled racists' attacks on Asian Americans (Loffman 2020).

John Cho, a Korean American actor, wrote an op-ed article in the Los Angeles Times, stating, "The pandemic is reminding us that our belonging is conditional. One moment we are Americans, the next we are all foreigners who 'brought' the virus here" (Cho 2020). With the information, images, and rhetoric that are constantly reproduced in the media, Asian Americans have become stigmatized in the public memory as objects of disgust and as carriers of the virus, have become the victims of violence, and are considered misplaced strangers who do not belong to U.S. society.

However, this paper suggests that the 1992 L.A. riots are mainly attributed to institutional racism, which manipulates and controls the cognitive systems as well as the behaviors of those who are affected by the institutional processes of remembering and forgetting the events. The political rhetoric in the media that victimizes Asian Americans as scapegoats functions as a means of institutional racism to maintain the specific interests by hiding the incompetence of the U.S. administrations that failed to prevent COVID-19 in "shadowed places," while highlighting inappropriate information on the coronavirus in return. This manipulation also reflects a self-deception and the pursuit of self-interests by those who benefit from it. Facing recent anti-Asian sentiment, another Korean actor, Daniel Kim, has commented, "Those who forget history are condemned to repeat it" (Tang 2020). Kim's statement may be reinterpreted from the perspective of institutional racism: The shameful history of racism against Korean (Asian) Americans, which was clearly revealed in the L.A. riots, has been deleted from the public memory of the majority in U.S. society. Having erased such memories of racism against the Korean (Asian) American minority, they could reject Asian American cultures and ethnic histories at any time, and conveniently make Asian Americans scapegoats without guilt. The current anti-Asian racism and violent attacks during the COVID-19 pandemic may be one of the vivid examples of the results from the forgotten history of the 1992 L.A. riots.

Formal institutional functions, the conflicts of group interests, and the universality of the sin of pride are all mingled with the issues in the L.A. riots. Niebuhr's thought about the sin of pride would make a fundamental tool for the analysis of these social problems and issues, and may suggest some alternatives to step forward to ensure justice in U.S. society. Most of all, the critical application of Niebuhr's thought about the universality of the sin of pride requires of us that we engage in critical self-reflection and in vigorous participation in justice for the victimized, the marginalized, the silenced, and the forgotten in the unjust social structures of U.S. society today.

Funding: This research received no external funding.

Conflicts of Interest: The author declares no conflict of interest. 


\section{References}

ABC7. 2020. Date Unknown. Transcript from ABC7 Eyewitness News Compiled in a Youtube Webpage. Available online: http://www.youtube.com/watch?v=5gCHS7CsjsE (accessed on 7 March 2020).

Abelmann, Nancy, and John Lie. 1995. Blue Dreams: Korean Americans and the Los Angeles Riots. Cambridge: Harvard University Press.

Abu-Lughod, Janet L. 2007. Race, Space, and Riots in Chicago, New York, and Los Angeles. Oxford and New York: Oxford University Press.

Bergesen, Albert, and Max Herman. 1998. Immigration, Race, and Riot: The 1992 Los Angeles Uprising. American Sociological Review 63: 39-54. [CrossRef]

Berry, LaVerle Bennette, Amanda Jones, Terence Powers, and Andrea Matles Savada. 1999. Media Interaction with the Public in Emergency Situations: Four Case Studies. Washington, DC: Federal Research Division, Library of Congress.

Cannon, Lou. 1997. Official Negligence: How Rodney King and the Riots Changed Los Angeles and the LAPD, 1st ed. New York: Times Books.

Chang, Edward T. 1999. New Urban Crisis: Korean-African Relations. In Koreans in the Hood: Conflict with African Americans. Edited by Kwang Chung Kim. Baltimore: Johns Hopkins University Press, pp. 39-59.

Cho, John. 2020. Op-Ed: John Cho: Coronavirus reminds Asian Americans like me that our belonging is conditional. Available online: https://www.latimes.com/opinion/story/2020-04-22/asian-american-discrimination-johncho-coronavirus (accessed on 3 May 2020).

Cho, Sumi K. 1993. Korean Americans vs. African Americans: Conflict and Construction. In Reading Rodney King: Reading Urban Uprising. Edited by Robert Gooding-Williams. New York: Routledge, pp. 196-214.

Cone, James H. 2011. The Cross and the Lynching Tree. Maryknoll: Orbis Books.

Douglas, Mary. 1986. How Institutions Think, 1st ed. The Frank W Abrams lectures. Syracuse: Syracuse University Press.

Dowler, Kenneth. 2004. Dual Realities? Criminality, Victimization, and the Presentation of Race on Local Television News. Journal of Crime and Justice 27: 79-99. [CrossRef]

Edy, Jill A. 1999. Journalistic Uses of Collective Memory. Journal of Communication 49. [CrossRef]

Fritze, John. 2019. Trump Used Words Like 'Invasion' and 'Killer' to Discuss Immigrants at Rallies 500 Times: USA TODAY Analysis. Available online: https://www.usatoday.com/story/news/politics/elections/2019/08/ 08/trump-immitrants-rhetoric-criticized-el-paso-dayon-shootings/1936742001/ (accessed on 20 June 2020).

Gamson, William A., and Andre Modigliani. 1987. The Changing Culture of Affirmative Action. Research in Political Sociology 3: 137-77.

Gilkey, Langdon. 2001. On Niebuhr: A Theological Study. Chicago: University of Chicago Press.

Gross, Kimberly, and Lisa D'Ambrosio. 2004. Framing Emotional Response. Political Psychology 25: 1-29. [CrossRef]

Herman, Edward S., and Noam Chomsky. 2002. Manufacturing Consent: The Political Economy of the Mass Media. New York: Pantheon Books.

HumanRightsWatch. 2020. Covid-19 Fueling Anti-Asian Racism and Xenophobia Worldwide. Available online: https://www.hrw.org/news/2020/05/12/covid-19-fueling-anti-asian-racism-and-xenophobia-worldwide (accessed on 13 May 2020).

Jacobs, Ronald N. 2000. Race, Media, and the Crisis of Civil Society. Cambridge Cultural Social Studies. Cambridge: Cambridge University Press.

Johansen, Bruce E. 1996. Race, Ethnicity, and the Media. In Mass Media and Society. Edited by Alan Wells and Ernest A. Hakanen. Greenwich: Ablex Publishing Corporation, pp. 513-25.

Kim, Churl Soo [김철수]. 2012. 10명중 7명 “폭동 재발 우려” [Seven out of Ten Respondents "Worry about the Riots to Occur Again"]. Available online: http://www.koreatimes.com/article/725833 (accessed on 10 March 2020).

Kim, Kwang Chung. 1999. Introduction. In Koreans in the Hood: Conflict with African Americans. Edited by Kwang Chung Kim. Baltimore: Johns Hopkins University Press, pp. 1-16.

Kim, Victoria, and Melissa Etehad. 2017. For First time, More L.A. Residents Believe New Riots Likely, New Poll Finds. Available online: https://www.latimes.com/local/lanow/la-me-riot-poll-20170426-story.html (accessed on 13 May 2020). 
Kurtz, Howard. 1993. Media Circus, 1st ed. New York: Times Books.

Lee, Jae Myung. 1999. The Significance of the L.A. Uprising and James Cone's Black Theology: Concentrating on Issues of Culture and Identity in U.S. Minorities. In Asian Americans and Christian Ministry. Edited by Inn Sook Lee and Timothy D. Son. Seoul: Voice Publishing House, pp. 34-48.

Loffman, Matt. 2020. Asian Americans Describe 'Gut Punch' of Racist Attacks during Coronavirus Pandemic. Available online: https://www.pbs.org/newshour/nation/asian-americans-describe-gut-punch-of-racistattacks-during-coronavirus-pandemic (accessed on 10 May 2020).

Min, Pyong Gap. 1996. Caught in the Middle. Berkeley: University of California Press.

Morrison, Peter A., and Ira S. Lowry. 1994. A Riot of Color: The Demographic Setting. In The Los Angeles Riots. Edited by Mark Baldassare. Boulder: Westview Press, pp. 19-46.

Niebuhr, Reinhold. 1957a. The Confession of a Tired Radical. In Love and Justice. Philadelphia: Westminster Press, pp. 120-24.

Niebuhr, Reinhold. 1957b. The Race Problem. In Love and Justice. Philadelphia: Westminster Press, pp. 129-32.

Niebuhr, Reinhold. 1996. The Nature and Destiny of Man. Louisville: Westminster John Knox Press, vol. 1. First published 1941.

Oh, Angela. 1994. No Longer a Black-White Equation: The Korean American Factor in Race Relations. In Civil Disorder: What Do We Know, How Should We Prepare? Washington, DC: Police Foundation, pp. 29-31.

Palumbo-Liu, David. 1994. Los Angeles, Asians, and Perverse Ventriloquisms: On the Functions of Asian America in the Recent American Imaginary. Public Culture 6: 365-81. [CrossRef]

Pieraccini, Tina. 1997. Women and the Media. In Mass Media and Society. Edited by Alan Wells and Ernest A. Hakanen. Greenwich: Ablex Pub. Corp., pp. 541-56.

Rieger, J. M. 2019. When a Rallygoer Suggested Shooting Immigrants in May, Trump Made a Joke. Available online: https://www.washingtonpost.com/politics/2019/08/05/when-rally-goer-suggested-shootingimmigrants-may-trump-made-joke/ (accessed on 20 June 2020).

Shah, Hemant, and Michael Charles Thornton. 2004. Newspaper Coverage of Interethnic Conflict: Competing Visions of America. Thousand Oaks: Sage.

Tang, Terry. 2020. PBS' 'Asian Americans' Explores Prejudice and Perseverance. Available online: https: //apnews.com/2217b85be67c3a38988a4dc52d52f710 (accessed on 10 May 2020).

Trounson, Rebecca, and Joel Rubin. 2012. Many say L.A. Is Safer 20 Years after 1992 Riots, Poll Finds. The Los Angeles Times, April 11.

Webster, William. 1994. The Failure and Lessons of Los Angeles. In Civil Disorder: What Do We Know How Should We Prepare? Washington, DC: The Police Foundation, p. 166.

West, Cornel. 1993. Race Matters. Boston: Beacon Press.

West, Traci C. 2006. Disruptive Christian Ethics: When Racism and Women's Lives Matter, 1st ed. Louisville: Westminster John Knox Press.

(C) 2020 by the author. Licensee MDPI, Basel, Switzerland. This article is an open access article distributed under the terms and conditions of the Creative Commons Attribution (CC BY) license (http://creativecommons.org/licenses/by/4.0/). 